\title{
Bisphenol A modulates the metabolic regulator oestrogen-related receptor- $\alpha$ in T-cells
}

\author{
Riccardo Cipelli*, Lorna Harries ${ }^{1, *}$, Katsuhiro Okuda², Shin'ichi Yoshihara², \\ David Melzer ${ }^{1}$ and Tamara Galloway
}

College of Life and Environmental Sciences, University of Exeter, Exeter EX4 4PS, UK, ${ }^{1}$ Epidemiology and Public Health, Peninsula College of Medicine and Dentistry, University of Exeter, Exeter, UK and ${ }^{2}$ Faculty of Pharmaceutical Sciences, Hiroshima International University, 5-1-1 Hirokoshingai, Kure, Hiroshima 737-0112, Japan

Correspondence should be addressed to T Galloway at School of Biosciences, Geoffrey Pope Building, Stocker Road, EX4 4QD Exeter, UK; Email: t.s.galloway@exeter.ac.uk

*(R Cipelli and L Harries are joint first authors)

\begin{abstract}
Bisphenol A (BPA) is a widely used plastics constituent that has been associated with endocrine, immune and metabolic effects. Evidence for how BPA exerts significant biological effects at chronic low levels of exposure has remained elusive. In adult men, exposure to BPA has been associated with higher expression of two nuclear receptors, oestrogen receptor- $\beta$ (ER $\beta$ ) and oestrogen-related-receptor- $\alpha$ (ERR $\alpha$ ), in peripheral white blood cells in vivo. In this study, we explore the expression of ESR2 (ERß) and ESRRA (ERR $\alpha$ ) in human leukaemic T-cell lymphoblasts (Jurkat cells) exposed to BPA in vitro. We show that exposure to BPA led to enhanced expression of ESRRA within $6 \mathrm{~h}$ of exposure (mean \pm s.E.M.: $1.43 \pm 0.08$-fold increase compared with the control, $P<0.05$ ). After $72 \mathrm{~h}$, expression of $E S R R A$ remained significantly enhanced at concentrations of BPA $\geq 1 \mathrm{nM}$. Oxidative metabolism of BPA by rat liver S9 fractions yields the potent oestrogenic metabolite, 4-methyl-2,4-bis(4-hydroxyphenyl)pent-1-ene (MBP). Exposure of cells to 1-100 nM MBP increased the expression of both ESRRA (significantly induced, $P<0.05$, at 1, 10, $100 \mathrm{nM})$ and ESR2 $(1.32 \pm 0.07$-fold increase at $100 \mathrm{nM}$ exposure, $\boldsymbol{P}<\mathbf{0 . 0 1}$ ). ERR $\alpha$ is a major control point for oxidative metabolism in many cell types, including T-cells. Following exposure to both BPA and MBP, we found that cells showed a decrease in cell proliferation rate. Taken together, these results confirm the bioactivity of BPA against putative T-cell targets in vitro at concentrations relevant to general human exposure.

Reproduction (2014) $\mathbf{1 4 7} 419-426$
\end{abstract}

\section{Introduction}

Bisphenol A (BPA) is a synthetic compound originally synthesised as an alternative to oestrogen (Dodds \& Lawson 1936). It is used widely as a monomer in polycarbonate plastics and in the epoxy resins that line food and drinks containers and is one of the world's

\footnotetext{
This paper forms part of a special issue of Reproduction on Endocrine Disrupters. This article was presented at the 7 th Copenhagen Workshop on Endocrine Disrupters, 28-31 May 2013. The meeting was supported by the Danish Ministry of the Environment - Environmental Protection Agency as an activity under the Danish Centre on Endocrine Disrupters. Publication of this special issue has been supported by the Society for Reproduction and Fertility. The opinions or views expressed in this special issue are those of the authors, and do not necessarily reflect the opinions or recommendations of the Danish Ministry of the Environment - Environmental Protection Agency or the Society for Reproduction and Fertility. The Guest Editors for this special issue were Anna-Maria Andersson, Hanne Frederiksen, Niels Erik Skakkebæk, Rigshospitalet, Denmark, Kenneth M Grigor, Western General Hospital, Edinburgh, UK and Jorma Toppari, University of Turku, Finland.
}

highest production volume chemicals (Ritter 2011). BPA is leached from food packaging into food and ingestion through food is a major route of human exposure, with additional exposures from dental sealants, inhalation of household dusts and dermal routes (Bailey \& Hoekstra 2011). This has led to ubiquitous exposure of the general population, with $>95 \%$ of people showing detectable levels of BPA in their urine (Calafat et al. 2008, Galloway et al. 2010, Vandenberg et al. 2010).

There has been a level of controversy over the adverse health consequences of exposure to BPA. Recent studies have demonstrated that human and wildlife populations are exposed to levels of BPA capable of negatively impacting on reproductive, developmental and metabolic endpoints in different wildlife species and laboratory animal studies (Calafat et al. 2008, Vandenberg et al. 2010). In addition, an increasing number of epidemiological studies have now shown that general population exposure to BPA is associated with adverse health outcomes. A recent literature review has found 
more than 90 studies linking BPA to human health (Rochester 2013). BPA exposures were positively associated with endocrine changes in men (Galloway et al. 2010, Meeker et al. 2010) and with negative effects on immune function (Clayton et al. 2011). Positive prospective associations have been reported between BPA exposure and a range of reproductive and developmental conditions including recurrent miscarriage (SugiuraOgasawara et al. 2005) and externalising behaviour scores in the offspring of exposed mothers (Braun et al. 2011). Urinary BPA concentrations were associated with cardiovascular disease diagnosis in large scale crosssectional (Lang et al. 2008, Melzer et al. 2010, 2012a) and longitudinal studies (Melzer et al. 2012b).

The plausibility of these associations and a comprehensive understanding of the risks posed by exposure to BPA are complicated by a lack of understanding of the mechanisms underlying its varied endocrine disruptive actions. Many of the physiological effects of BPA have been studied in relation to its widely reported activity as an oestrogen agonist (Lee et al. 2003, Chapin et al. 2008). A number of additional receptor-mediated effects have been reported including anti-androgen activity (Bonefeld-Jørgensen et al. 2007), thyroid hormone disruption (Moriyama et al. 2002), altered pancreatic $\beta$-cell function (Ropero et al. 2008, Soriano et al. 2012) and obesity-promoting effects (Newbold et al. 2008, Marmugi et al. 2012), binding to oestrogen-related receptor gamma (ERRY; Takayanagi et al. 2006, Okada et al. 2008) and activation of peroxisome proliferatoractivated receptor- $\gamma$ (PPAR $\gamma)$-mediated pathways (Kwintkiewicz et al. 2010). A confirmation of BPA interaction with a large number of different pathways was obtained from computational analysis of the extensive in vitro tests carried out within the ToxCast program (Reif et al. 2010). Comprehensive reviews of the available data highlight both the complexity of BPA's biochemical and molecular interactions, and that these varied receptor systems and molecular pathways may be differentially affected in different target tissues and species (Wetherill et al. 2007, Thayer \& Belcher 2011).

In order to gain a better understanding of the molecular mechanisms underlying the health effects of BPA, we have recently studied the in vivo expression of a panel of oestrogen receptor (ER)-ERR and androgen receptor genes in the peripheral blood leukocytes taken from 96 adult men (Melzer et al. 2011). We found that there were positive associations between higher BPA concentrations and higher expression of two genes, ESR2 (oestrogen receptor 2, ER $\beta$ ) and ESRRA (oestrogenrelated receptor alpha, ERR $\alpha$ ). This finding is of interest because it suggests that BPA and/or its metabolites are bioactive in the human body and that associations with hormone signalling and related disorders are biologically plausible. ER $\beta$ is important in mediating the physiological actions of oestrogens in target tissues including prostate, colon, cardiovascular and CNS
(Imamov et al. 2005), with a tissue distribution and ligand specificity that is distinct from that of $E R \alpha$. ERR $\alpha$ belongs to the NR3 $\beta$ orphan nuclear receptor family subgroup, consisting of ERR $\alpha, \beta$ and $\gamma$. Although responsive to some synthetic oestrogens, there are no known naturally occurring ligands for ERR $\alpha$ (Willy et al. 2004). Genetic studies on mice showed that ERR subtypes are involved in mitochondrial biogenesis, oxidative phosphorylation and lipid metabolism (Tremblay \& Giguere 2007). Both ERR $\alpha$ and $\gamma$ are essential for proper cardiac function (Huss et al. 2007) and may play a broader role in metabolic homeostasis (Tennessen et al. 2011). The functional relevance of changes in ER $\beta$ and ERR $\alpha$ in blood leukocytes has not been comprehensively determined, although ERR $\alpha$ is reported to be a selective transcriptional regulator of certain T-cell effector functions, facilitating gene expression and glucose and mitochondrial metabolism during T-cell growth and proliferation (Michalek et al. 2011).

The objectives of the current study were to explore the expression of the ESR2 and ESRRA genes in human leukaemic T-cell lymphoblasts (Jurkat cells) exposed to BPA and one of its metabolites, in vitro. We used Jurkat cells because they are an amenable in vitro lymphocyte model and our in vivo expression studies highlighted the potential sensitivity of lymphocytes to the effects of BPA; BPA exposure is known to have effects on cytokine production in T-cells in vitro (Yan et al. 2008) and ERR $\alpha$ has many functions, including modulation of the immune response (Ranhotra 2012). In addition, we investigated the effect of a putative metabolite of BPA: oxidative metabolism of BPA by rat or human liver S9 fractions yields the potent oestrogenic metabolite 4-methyl-2,4-bis(4-hydroxyphenyl)pent-1-ene (MBP), which has around 1000-fold higher oestrogenic activity than BPA (Okuda et al. 2010). 3D models of MBP suggest that its structure allows for interaction with amino acid residues in $E R \alpha$ and $E R \beta$ that are important for binding of oestradiol by these receptors (Baker \& Chandsawangbhuwana 2012), but which are absent from BPA. We compared the expression of ER $\beta$ and ERR $\alpha$ following exposure to $17 \alpha$-ethinylestradiol $\left(\mathrm{EE}_{2}\right), \mathrm{MBP}$ and $\mathrm{BPA}$ at environmentally relevant concentrations and over different time intervals. As ERR $\alpha$ is a major control point for oxidative metabolism in many cell types, including T-cells, we determined the effects of BPA and MBP exposure on downstream end-points such as cell proliferation and ATP content.

\section{Materials and methods Synthesis of MBP}

MBP was synthesised at Hiroshima International University as described previously (Yoshihara et al. 2004). MBP was in the form of a white powder with a melting point at $130.5-132{ }^{\circ} \mathrm{C}$; purity was certified from the narrow melting point range 
obtained and the single peak obtained by HPLC. The ${ }^{1} \mathrm{H}$ NMR data $\left(400 \mathrm{MHz}, \mathrm{CDCl}_{3}\right)$ of authentic MBP obtained using a JEOL, ALPHA-FT NMR Spectrometer were $\delta 1.20(\mathrm{~s}, 6 \mathrm{H}), 2.74$ $(\mathrm{s}, 2 \mathrm{H}), 4.64(\mathrm{~s}, 1 \mathrm{H}), 4.71(\mathrm{~d}, 1 \mathrm{H}, J=2.0 \mathrm{~Hz}), 4.74(\mathrm{~s}, 1 \mathrm{H}), 5.07$ $(\mathrm{d}, 1 \mathrm{H}, J=2.0 \mathrm{~Hz}), 6.67(\mathrm{~d}, 2 \mathrm{H}, J=8.8 \mathrm{~Hz}), 6.67(\mathrm{~d}, 2 \mathrm{H}$, $J=8.4 \mathrm{~Hz}), 7.09(\mathrm{~d}, 2 \mathrm{H}, J=8.8 \mathrm{~Hz}), 7.12(\mathrm{~d}, 2 \mathrm{H}, J=8.8 \mathrm{~Hz})$. Chemical shifts are reported in ppm downfield from the peak of tetramethylsilane used as an internal standard. Splitting patterns are designated as 's and $d$ ' indicating 'singlet and doublet' respectively.

\section{Cell culture, dosing and exposure}

All further experiments were carried out at the University of Exeter. Jurkat cells, human leukaemic T-cell lymphoblasts, were purchased (catalogue number: 88042803) and cultured in suspension in RPMI-1640 without phenol red (Sigma-Aldrich Company Ltd.), supplemented with $10 \%$ feotal bovine serum, stripped with charcoal-dextran (Gibco) and $200 \mathrm{mM}$ L-glutamine (Sigma-Aldrich). The cells were grown in the suspensions at the temperature of $37{ }^{\circ} \mathrm{C}$ in $5 \% \mathrm{CO}_{2}$ and the culture was maintained between 0.5 and $5 \times 100.000$ cells $/ \mathrm{ml}$. Before the experiments, cells were grown in a single tissue culture flask angled neck and vented cap. Medium was changed ahead of the start of each experiment and it was not changed during the treatments. Cell viability was assayed with Trypan blue (Sigma-Aldrich) staining (dilution: 1/10th of $100 \mu \mathrm{l}$ culture volume). Cell viability was always above $80 \%$. The cells were exposed to $\mathrm{EE}_{2}$ ( $\geq 98 \%$, Sigma-Aldrich), BPA ( $\geq 99 \%$, Sigma-Aldrich) and to the oxidative metabolite of BPA, MBP, synthesised as described earlier. Exposure experiments were repeated at least twice and included between three and eight replicates for each treatment.

\section{Exposure to $\mathrm{EE}_{2}$}

Exposures were carried out in $25 \mathrm{~cm}^{2}$ flasks $(n=3) ; 1 \mu \mathrm{M} \mathrm{EE}_{2}$ and the solvent control $(0.001 \%$ ethanol $)$ were added to the cell culture medium and total RNA extraction was performed at the time point $0,6,24,36,48,72 \mathrm{~h}$, chosen to provide an overview of the time-dependent activation of the target genes across a time interval of 3 days. The selection of a time window of $72 \mathrm{~h}$ was based on previous studies present in the literature (Richter et al. 2007). During each time point, three flasks from the control and the exposed group were randomly selected, sampled for RNA extraction and then discarded.

\section{Exposure to BPA and MBP}

Jurkat cells were divided into treatment and control flasks, $1 \mu \mathrm{M}$ BPA and solvent control $(0.001 \%$ ethanol) were added accordingly. The cells were then seeded onto 24-well plates. Total RNA extraction was performed at time point $0,6,24,36$, 48, $72 \mathrm{~h}$. When exposures of 1, 10 and $100 \mathrm{nM}$ BPA concentrations were then tested, mRNA expression was measured at a single time-point (72 h). The time-point was selected based on the results of the previous exposures to $1 \mu \mathrm{M}$ $\mathrm{EE}_{2}$ and $1 \mu \mathrm{M}$ BPA. Treatments and solvent controls were added according to the different concentrations as described previously. Treatments were replicated in eight wells per experiment and the control in six. Two parallel experiments were conducted; results were checked for statistical differences and then tabulated and merged. Similarly, a set of experiments was performed exposing cells to MBP that was tested at 1, 10, $100 \mathrm{nM}$ concentrations. Study design, replication and sampling time were as the ones described earlier.

\section{Real-time RT-PCR measurement of gene expression in target genes}

Total RNA was extracted after sampling using the RNeasy Mini Kit from Qiagen according to the manufacturer's instructions. RNA yield was quantified using a NanoDrop spectrophotometer. Total RNA (500 ng) was reversed transcribed in $20 \mu \mathrm{l}$ reactions using the Superscript III VILO kit (Invitrogen). Real-time PCR amplifications were performed on the $\mathrm{ABI}$ 7900HT platform using 96-well plates (Applied Biosystems). Each well contained $5 \mu$ l TaqMan $2 \times$ universal master mix (no

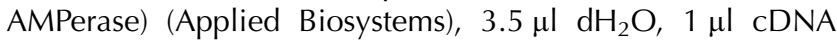
template and $0.5 \mu \mathrm{l}$ probe. Cycling conditions were $50{ }^{\circ} \mathrm{C}$ for $2 \mathrm{~min}, 95^{\circ} \mathrm{C}$ for $10 \mathrm{~min}$ followed by 50 cycles at $95{ }^{\circ} \mathrm{C}$ for $15 \mathrm{~s}$ and $60{ }^{\circ} \mathrm{C}$ for $1 \mathrm{~min}$. The expression levels of the genes ESR2 $(E R \beta)$ and $\operatorname{ESRRA}(\mathrm{ERR} \alpha)$ were assessed through relative quantification using the $2^{-\Delta \Delta C t}$ method (Livak \& Schmittgen 2001). Data are presented as the fold-change in gene expression relative to three endogenous control transcripts and normalised to the levels of the test transcripts in the untreated control. PCR signal of the target transcripts was standardised using three housekeeping (HK) genes: $\beta 2$ microglobulin $(B 2 M)$, hypoxanthine phosphoribosyl- transferase 1 (HPRT1) and family with sequence similarity 102 (FAM102A). This was done to account for differences in the amount of cDNA that is loaded into each PCR wells and differences between plates. The expression of each of the five genes was measured in triplicate for each sample. A minimum of three HK genes is recommended for a reliable standardisation factor and to reduce errors in real-time quantitative RT-PCR data (Vandesompele et al. 2002). B2M and HPRT1 are widely used HK genes (Vandesompele et al. 2002) while FAM102A expression was shown empirically not to be influenced by BPA exposure in our previous experiments. Probes were inventoried Applied Biosystems assays, with the exception of the ESRRA probe, which was a custom assay (probe and primer sequences available on request).

\section{ATP measurements and cell count}

Levels of intracellular ATP were measured using an ATP Assay kit (Enliten, Promega). Assays were performed on the Infinite F200 microplate luminometer (Tecan and Beckman, Männedorf, Switzerland) combined with 96-well white microplates. Cell count was carried out using the particle counting Multisizer Coulter Counter (Beckman, USA).

\section{Statistical analysis}

Values in tables and graphs are expressed as mean \pm s.E.M. (unless otherwise specified). Two-way factorial ANOVA was 
used to test the interaction between treatment and time of exposure when multiple time-points were considered. Data were checked for the normality of distribution and variance homogeneity. Where the overall ANOVA showed significance, post-hoc comparisons between treatment and its control were performed. When only the effect of different treatments was tested, one-way ANOVA was used followed by Bonferroni post-hoc test. $P$ value $<0.05$ was considered significant.

\section{Results}

\section{Time and dose responsiveness of ESR2 and ESRRA in Jurkat cells}

All target genes (ESR2, ESRRA) and HK genes (B2M, HPRT1, FAM102) were empirically checked and consistently detected in Jurkat cells. The oestrogen responsiveness of cells was initially tested using $\mathrm{EE}_{2}$ (Naciff et al. 2010). A time-dependent increase in expression of both ESR2 and ESRRA target gene transcripts was seen (Fig. 1A and B) following exposure to $1 \mu \mathrm{M} \mathrm{EE}_{2}$. For ESR2, a monotonic increase was seen, with maximum intensity of expression at $72 \mathrm{~h}$ and indication of an increasing trend (Fig. 1A). On the other hand, ESRRA showed a non-monotonic trend with a non-significant increase in gene expression after $6 \mathrm{~h}$, a subsequent drop and a significant increase at 48 and $72 \mathrm{~h}$ (mean \pm s.E.M., up to twofold increase \pm 0.09 compared with the control, $P<0.05)$. Exposure to $1 \mu \mathrm{M}$ BPA under the same conditions produced a similar level of increase (Fig. 1C and D). The time profile of BPA exposure indicates that ESR2 expression was significantly induced compared with the control after $36 \mathrm{~h}$ $(1.36 \pm 0.10$-fold increase, $P<0.05)$. Expression of ESRRA again showed a non-monotonic response: a statistically significant increase was registered after only $6 \mathrm{~h}$ of exposure to BPA followed by a drop at $24 \mathrm{~h}$ and a second significant increase at $48 \mathrm{~h}(1.58 \pm 0.08$-fold increase, $P<0.01$ ), remaining elevated for the duration
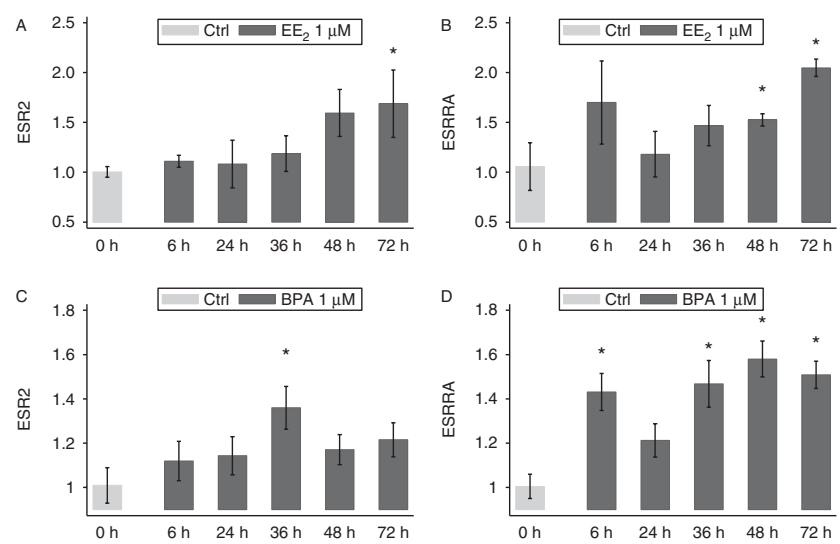

Figure 1 Gene expression intensity as a function of time following exposure of Jurkat cells to $1 \mu \mathrm{M} \mathrm{EE}_{2}$ ( $\mathrm{A}$ and $\mathrm{B}$ ) or $1 \mu \mathrm{M} \mathrm{BPA}(\mathrm{C}$ and $\mathrm{D})$. Values are expressed as fold-change increase compared with each time-point control (mean \pm s.E.M.). ${ }^{*} P<0.05$. of the experiment. Overall, exposure to a high concentration of BPA showed a stronger and quicker increase in mRNA expression levels of ESRRA than ESR2.

The cell were exposed to environmentally relevant concentrations (1-100 nm) of BPA and to MBP, its oxidative metabolite (Fig. 2). The ESR2 mRNA expression level did not change in the treatment groups exposed to increasing concentrations of BPA (Fig. 2A). There was, however, a significant increase in ESR2 expression following $72 \mathrm{~h}$ exposure to $100 \mathrm{nM} \mathrm{MBP}$ : the average value in the treatment group (mean \pm S.E.M., $1.32 \pm 0.075, n=16)$ was significantly higher than the control group (1.01 $\pm 0.046, n=12$, Fig. 2C). For ESRRA, significantly increased expression was seen following exposure to both BPA and MBPat all concentrations from $1 \mathrm{nM}$ upwards (Fig. 2B and D). Jurkat cells exposed to increasing concentrations of BPA showed levels of ESRRA expression increased by up to $82 \%( \pm 13 \%$, $n=16$ ). Similar results were registered after exposure to MBP (Fig. 2C and D).

\section{Effects of BPA and MBP on cell proliferation and ATP}

Jurkat cells exposed to $100 \mathrm{nM}$ BPA showed a decreased proliferation after $48 \mathrm{~h}$ compared with the control (Fig. 3). After $72 \mathrm{~h}$, the difference in cell count between exposed and control groups was greater $(P<0.001)$. There was considerable variability in the ATP content of cells which were generally lower following exposure to either compound (Fig. 3B). However, the levels of ATP measured in control and exposed group and adjusted for cell numbers were not significantly different at either time point $(P=0.07)$.

\section{Discussion}

We have previously reported that human exposure to BPA is associated with the activation of the oestrogen-responsive genes ESR2 and ESRRA measured in the peripheral blood leukocytes in the general adult population (Melzer et al. 2011). The ERs and ERRs share common targets and control overlapping transcriptional regulatory networks. This makes them of high interest for investigating the effects of BPA and related compounds showing diverse oestrogen-like effects. The aim of this study was to further explore the expression of ESR2 and ESRRA in human leukaemic T-cell lymphoblasts exposed to BPA and of a metabolite under laboratory conditions where potentially confounding variables could be controlled. We show here that BPA at environmentally relevant concentrations can cause changes to hormone sensitive gene transcripts and that this has physiological consequences in altering cell growth rate in T-cells. This is important because these results taken together with our previous study suggest that ESRRA gene expression can be significantly modulated by BPA and its 

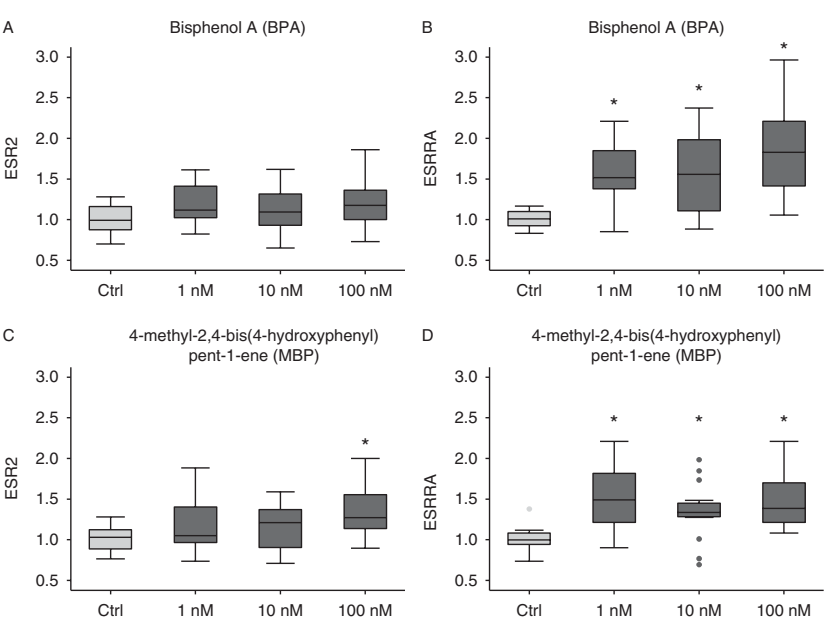

Figure 2 Gene expression intensity after $72 \mathrm{~h}$ exposure of Jurkat cells to 1-10-100 nM BPA (A and B) or 1-10-100 nM MBP (C and D). Values are expressed as fold-change increase compared with control (Ctrl). Box plots follow Tukey's rules and outliers are represented by dots (see D). ${ }^{*} P<0.05$.

metabolites in human blood cells both in laboratory and in vivo conditions and, hence, imply that BPA is capable of plausible bioactivity in the human body.

Of particular interest is what we believe to be the first report of a significant increase in expression of ESRRA following exposure to both $\mathrm{EE}_{2}$ and BPA in T-cells. ERR $\alpha$ is a regulator of cell metabolism across many different cell types (Giguère 2008, Villena \& Kralli 2008) and has a central role in the regulation of energy homeostasis and adaptive oxygen capacity. Activity of ERR $\alpha$, which has no known endogenous ligands, is known to be regulated at the protein level; activity is highly sensitive to co-regulatory proteins involved in energy homeostasis such as the steroid receptor co-activator, peroxisome proliferation activation receptor gamma co-activators (PGC) $1 \alpha / \beta$ and the co-repressor receptor-interacting protein 140 (RIP140). Our data show additional regulation at the level of the mRNA, indicating both the importance of transcriptional regulation (Giguère 2008) and highlighting a novel target for the action of endocrine-disrupting chemicals in the body.

The activity of ERR $\alpha$ as a transcriptional regulator in T-cells has recently been described in detail (Michalek et al. 2011). T-cell activation and differentiation are energetically demanding processes and considerable metabolic reprogramming is required to enable the rapid proliferation and functional responsiveness of $\mathrm{T}$ effector (Teff) and regulator (Treg) cell subsets. Accordingly, ERR $\alpha$ appears to play a key role in Teff cell function through the induction of metabolic gene expression to programme mitochondria for aerobic glycolysis and to regulate glycolytic metabolism more generally. Interference in this process by BPA could in theory alter the balance of Teff and Treg cells, leading to immunotoxic effects. Although the full significance of ERR $\alpha$ expression in the
Jurkat lymphoblastic cell line that we have used here is not yet known, we were able to show a significant inhibition of cell proliferation following exposure to $100 \mathrm{~nm} \mathrm{BPA}$, consistent with this theory.

It would be of considerable interest to determine the effects of BPA on ESRRA expression and metabolic activity in a wider range of different cell types, especially in light of the associations previously reported between exposure to BPA and metabolic diseases (Melzer et al. 2012a, 2012b). $E R R \alpha$ is present in a wide variety of cell types and is highly expressed in cells with elevated metabolic demand such as heart, skeletal muscle and brown adipose tissue (Eichner \& Giguère 2011). It is suggestive to note that BPA has shown affinity for the metabolic regulator PPAR $\gamma$ in a previous study (Kwintkiewicz et al. 2010) and in addition there is evidence of agonist interaction between PPAR $\gamma$ and ERR $\alpha$ (Willy et al. 2004) and PPAR $\gamma$ and ER $\beta$ (Foryst-Ludwig et al. 2008). More recently, Marmugi et al. (2012) have used a transcriptomic approach to show that exposure of male CD1 mice to low doses of BPA was able to influence de novo fatty acid synthesis through alterations in lipogenic genes. These results suggest that the role of BPA in influencing metabolic processes is certainly deserving of further attention.

BPA metabolism and excretion are believed to take place largely in the first $24 \mathrm{~h}$ after exposure, although there are studies suggesting this could take longer (Stahlhut et al. 2009, Sieli et al. 2011) or may be stored in human adipose tissue (Rubin \& Soto 2009). After liver metabolism, glucuronide-conjugated BPA shows little or no affinity for nuclear receptors (Matthews et al. 2001), although a recent study has shown that BPA glucuronidated compound can be active in vitro through a rapid membrane-initiated signalling pathway (Viñas et al. 2013). In human biomonitoring studies, analyses carried out with blood, serum or plasma samples
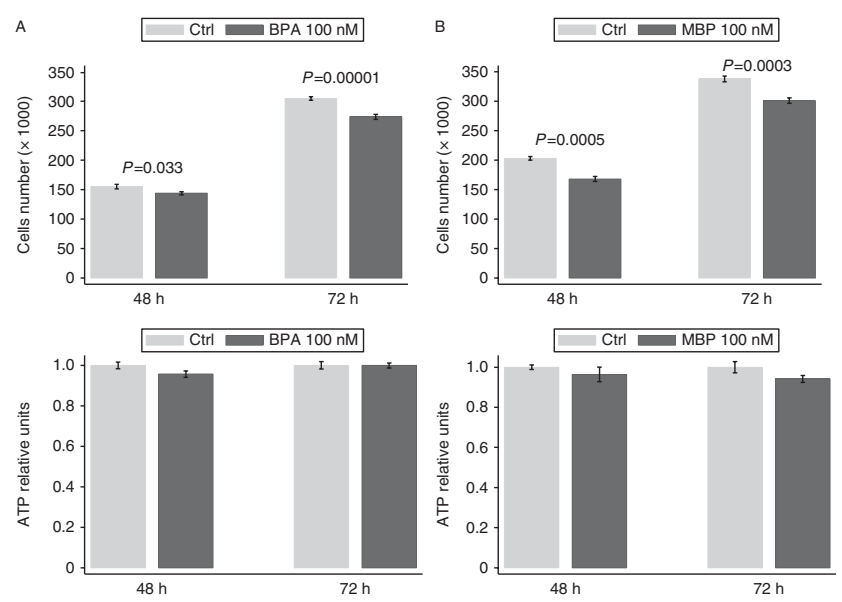

Figure 3 Growth rate decrease ( $\mathrm{A}$ and $\mathrm{B}$ ) in Jurkat cells exposed to $100 \mathrm{nM} \mathrm{BPA}$ and $100 \mathrm{nM} \mathrm{MBP}$ after 48 and $72 \mathrm{~h}$ compared with control. Values are expressed as mean \pm s.E.M. $P$ values are reported above the bars when $P<0.05$. 
measured unconjugated BPA which is considered the portion of BPA not yet metabolised by the liver and so capable of being bioactivated. A recent review of 16 of these studies indicates that the range of blood/serum BPA concentrations spans between 0.5 and $2.5 \mathrm{ng} / \mathrm{ml}$ (Vandenberg et al. 2010). Given the range of concentrations chosen for our experiments $(1-10 \mathrm{nM} ; 1 \mathrm{nM}$ $\mathrm{BPA}=0.228 \mathrm{ng} / \mathrm{ml}$ ), we could argue that this reflects very well the population internal exposure to unconjugated BPA. The same range of concentration has been taken as reference in other major experimental studies (Richter et al. 2007, Hugo et al. 2008), whilst a recent review of human toxicokinetic studies suggests that the circulating concentration may be lower than this (Doerge \& Fisher 2011).

Oxidative cleavage of BPA to form the oestrogenically active metabolite MBP was first reported in rat liver and Okuda et al. (2010) reported that MBP was 500-fold more potent than BPA in inducing dose-dependent changes in the expression of ESR 1 and ESR2 mRNA. In this study, we have shown a small but significant upregulation of ER $\beta$ following exposure of cells to $100 \mathrm{nM} \mathrm{MBP}$, which would agree with an enhanced oestrogenic activity of this compound. In addition, MBP showed a near identical pattern of upregulation of ESRRA, with a significant increase in expression seen at concentrations as low as $1 \mathrm{nM}$. The full significance of this metabolite in humans is not yet known. MBP is formed by recombination of the radical fragment of $\mathrm{BPA}$, and its formation requires both microsomal and cytosolic fractions. A similar mechanism of metabolism has been reported in sewage sludge bacterial isolates (Spivack et al. 1994). Although the glucuronate/sulphate conjugates are the main metabolites excreted in urine, a comparison of phase 1 metabolism in human and rat liver microsomes has identified an additional oxidation product, BPA-catechol, as a minor metabolite $(\sim 10 \%)$ in both species, and BPA-catechol is certainly measurable in human urine (Ye et al. 2011). As BPA-catechol is also reported to possess oestrogenic activity, further investigation of the pathways of metabolism of BPA and related compounds in humans would seem to be a priority for future research.

\section{Conclusions}

We provide here a first report of the enhanced expression of two oestrogen responsive genes, ESR2 (ER $\beta$ ) and ESRRA $(E R R \alpha)$ in human leukaemic T-cell lymphoblasts exposed to BPA at environmentally relevant concentrations. Significantly enhanced expression of both of these transcription factors in vivo has previously been associated with exposure to BPA in peripheral white blood cells in adult men (Melzer et al. 2011). As ERR $\alpha$ is a major control point for oxidative metabolism in many cell types, including T-cells, we also determined the effects of BPA and MBP exposure on cell growth and ATP content and showed a significant inhibition of cell proliferation at nanomolar concentrations of both compounds. These results add to the weight of evidence for how BPA is able to exert significant biological effects at chronic low levels of exposure and identify a novel metabolic target for the action of endocrine disrupting chemicals.

\section{Declaration of interest}

The authors declare that there is no conflict of interest that could be perceived as prejudicing the impartiality of the research reported.

\section{Funding}

This article is based on work presented at the 7th Copenhagen Workshop (COW) on Endocrine Disrupters, which was supported by the Danish Ministry of the Environment Environmental Protection Agency. Publication of this special issue was supported by the Society for Reproduction and Fertility. All authors declare that they have no conflict of interest relating to the sponsors of the meeting. Prof. T Galloway received a financial contribution towards travel expenses to attend the COW meeting from the sponsors.

\section{Author contribution statement}

T Galloway, L Harries and D Melzer were responsible for study concept, design, interpretation of data and preparation of manuscript. R Cipelli contributed to study design, practical work, interpretation of data and preparation of manuscript. K Okuda and S Yoshihara prepared and supplied chemical metabolites and contributed towards preparation of the manuscript.

\section{Acknowledgements}

The authors are grateful to Paul Holcroft for excellent technical support. This work was made possible by funding of a $\mathrm{PhD}$ studentship to Riccardo Cipelli from University of Exeter internal funds.

\section{References}

Bailey AB \& Hoekstra EJ 2011 Background Paper on Sources and Occurrence of Bisphenol A Relevant for Exposure of Consumers. In FAO/WHO Expert Meeting on Bisphenol A (BPA). Ottawa, Canada: WHO press. http://www.who.int/foodsafety/chem/chemicals/2_source_ and_occurrence.pdf

Baker ME \& Chandsawangbhuwana C 2012 3D models of MBP, a biologically active metabolite of bisphenol A, in human estrogen receptor $\alpha$ and estrogen receptor $\beta$. PLOS ONE 7 e46078. (doi:10.1371/ journal.pone.0046078)

Bonefeld-Jørgensen EC, Long M, Hofmeister MV \& Vinggaard AM 2007 Endocrine-disrupting potential of bisphenol A, bisphenol A dimethacrylate, 4- $n$-nonylphenol, and 4- $n$-octylphenol in vitro: new data and a brief review. Environmental Health Perspectives 115 69-76. (doi:10.1289/ ehp.9368)

Braun JM, Kalkbrenner AE, Calafat AM, Bernert JT, Ye X, Silva MJ, Barr DB, Sathyanarayana S \& Lanphear BP 2011 Variability and predictors of urinary bisphenol A concentrations during pregnancy. Environmental Health Perspectives 119 131-137. (doi:10.1289/ehp.1002366) 
Calafat AM, Ye X, Wong LY, Reidy JA \& Needham LL 2008 Exposure of the US population to bisphenol A and 4-tertiary-octylphenol: 2003-2004. Environmental Health Perspectives 116 39-44. (doi:10.1289/ehp.10753)

Chapin RE, Adams J, Boekelheide K, Gray LE Jr, Hayward SW, Lees PSJ, McIntyre BS, Portier KM, Schnorr TM \& Selevan SG 2008 NTP-CERHR expert panel report on the reproductive and developmental toxicity of bisphenol A. Birth Defects Research. Part B, Developmental and Reproductive Toxicology 83 157-395. (doi:10.1002/bdrb.20147)

Clayton EMR, Todd M, Dowd JB \& Aiello AE 2011 The impact of bisphenol A and triclosan on immune parameters in the US population, NHANES 2003/2006. Environmental Health Perspectives 119 390-396. (doi:10. 1289/ehp.1002883)

Dodds E \& Lawson W 1936 Synthetic estrogenic agents without the phenanthrene nucleus. Nature 137 996. (doi:10.1038/137996a0)

Doerge DR \& Fisher JW 2011 Background Paper on Metabolism and Toxicokinetics of Bisphenol A. In: FAO/WHO Expert Meeting on Bisphenol A (BPA). Ottawa, Canada: WHO press. http://www.who.int/ foodsafety/chem/chemicals/4_metabolism_and_toxicokinetics.pdf

Eichner LJ \& Giguère V 2011 Estrogen related receptors (ERRs): a new dawn in transcriptional control of mitochondrial gene networks. Mitochondrion 11 544-552. (doi:10.1016/j.mito.2011.03.121)

Foryst-Ludwig A, Clemenz M, Hohmann S, Hartge M, Sprang C, Frost N, Krikov M, Bhanot S, Barros R \& Morani A 2008 Metabolic actions of estrogen receptor $\beta$ (ER $\beta)$ are mediated by a negative cross-talk with PPAR $\gamma$. PLoS Genetics 4 e1000108. (doi:10.1371/journal.pgen. 1000108)

Galloway T, Cipelli R, Guralnik J, Ferrucci L, Bandinelli S, Corsi AM, Money C, McCormack P \& Melzer D 2010 Daily bisphenol A excretion and associations with sex hormone concentrations: results from the InCHIANTI Adult Population Study. Environmental Health Perspectives 118 1603-1608. (doi:10.1289/ehp.1002367)

Giguère V 2008 Transcriptional control of energy homeostasis by the estrogen-related receptors. Endocrine Reviews 29 677-696. (doi:10.1210/ er.2008-0017)

Hugo ER, Brandebourg TD, Woo JG, Loftus J, Alexander JW \& Ben-Jonathan N 2008 Bisphenol A at environmentally relevant doses inhibits adiponectin release from human adipose tissue explants and adipocytes. Environmental Health Perspectives 116 1642-1647. (doi:10.1289/ehp.11537)

Huss JM, Imahashi K-I, Dufour CR, Weinheimer CJ, Courtois M, Kovacs A, Giguere V, Murphy E \& Kelly DP 2007 The nuclear receptor ERR $\alpha$ is required for the bioenergetic and functional adaptation to cardiac pressure overload. Cell Metabolism 6 25-37. (doi:10.1016/j.cmet.2007. 06.005)

Imamov O, Shim GJ, Warner M \& Gustafsson JA 2005 Estrogen receptor $\beta$ in health and disease. Biology of Reproduction 73 866-871. (doi:10.1095/biolreprod.105.043497)

Kwintkiewicz J, Nishi Y, Yanase T \& Giudice LC 2010 Peroxisome proliferator-activated receptor- $\gamma$ mediates bisphenol A inhibition of FSH-stimulated IGF-1, aromatase, and estradiol in human granulosa cells. Environmental Health Perspectives 118 400-406. (doi:10.1289/ ehp.0901161)

Lang IA, Galloway TS, Scarlett A, Henley WE, Depledge M, Wallace RB \& Melzer D 2008 Association of urinary bisphenol A concentration with medical disorders and laboratory abnormalities in adults. Journal of the American Medical Association 300 1303-1310. (doi:10.1001/jama.300. 11.1303)

Lee HJ, Chattopadhyay S, Gong EY, Ahn RS \& Lee K 2003 Antiandrogenic effects of bisphenol $\mathrm{A}$ and nonylphenol on the function of androgen receptor. Toxicological Sciences 75 40-46. (doi:10.1093/toxsci/kfg150)

Livak KJ \& Schmittgen TD 2001 Analysis of relative gene expression data using real-time quantitative PCR and the $2-\Delta \Delta C T$ method. Methods 25 402-408. (doi:10.1006/meth.2001.1262)

Marmugi A, Ducheix S, Lasserre F, Polizzi A, Paris A, Priymenko N, Bertrand-Michel J, Pineau T, Guillou H \& Martin PGP 2012 Low doses of bisphenol A induce gene expression related to lipid synthesis and trigger triglyceride accumulation in adult mouse liver. Hepatology 55 395-407. (doi:10.1002/hep.24685)

Matthews JB, Twomey K \& Zacharewski TR 2001 In vitro and in vivo interactions of bisphenol $\mathrm{A}$ and its metabolite, bisphenol A glucuronide, with estrogen receptors $\alpha$ and $\beta$. Chemical Research in Toxicology 14 149-157. (doi:10.1021/tx0001833)
Meeker JD, Calafat AM \& Hauser R 2010 Urinary bisphenol A concentrations in relation to serum thyroid and reproductive hormone levels in men from an infertility clinic. Environmental Science \& Technology 44 1458-1463. (doi:10.1021/es9028292)

Melzer D, Rice NE, Lewis C, Henley WE \& Galloway TS 2010 Association of urinary bisphenol A concentration with heart disease: evidence from NHANES 2003/06. PLOS ONE 5 e8673. (doi:10.1371/journal.pone. 0008673)

Melzer D, Harries L, Cipelli R, Henley W, Money C, McCormack P, Young A, Guralnik J, Ferrucci L, Bandinelli S et al. 2011 Bisphenol A exposure is associated with in vivo estrogenic gene expression in adults. Environmental Health Perspectives 119 1788-1793. (doi:10.1289/ehp. 1103809)

Melzer D, Gates P, Osborne NJ, Henley WE, Cipelli R, Young A, Money C, McCormack P, Schofield P, Mosedale D et al. 2012a Urinary bisphenol A concentration and angiography-defined coronary artery stenosis. PLoS ONE 7 e43378. (doi:10.1371/journal.pone.0043378)

Melzer D, Osborne NJ, Henley WE, Cipelli R, Young A, Money C, McCormack P, Luben R, Khaw KT, Wareham NJ et al. 2012b Urinary bisphenol A concentration and risk of future coronary artery disease in apparently healthy men and women. Circulation 125 1482-1490. (doi:10.1161/CIRCULATIONAHA.111.069153)

Michalek RD, Gerriets VA, Nichols AG, Inoue M, Kazmin D, Chang C-Y, Dwyer MA, Nelson ER, Pollizzi KN, Ilkayeva O et al. 2011 Estrogenrelated receptor- $\alpha$ is a metabolic regulator of effector T-cell activation and differentiation. PNAS 108 18348-18353. (doi:10.1073/pnas. 1108856108)

Moriyama K, Tagami T, Akamizu T, Usui T, Saijo M, Kanamoto N, Hataya $Y$, Shimatsu A, Kuzuya H \& Nakao K 2002 Thyroid hormone action is disrupted by bisphenol $\mathrm{A}$ as an antagonist. Journal of Clinical Endocrinology and Metabolism 87 5185-5190. (doi:10.1210/jc.2002020209)

Naciff JM, Khambatta ZS, Reichling TD, Carr GJ, Tiesman JP, Singleton DW, Khan SA \& Daston GP 2010 The genomic response of Ishikawa cells to bisphenol A exposure is dose- and time-dependent. Toxicology 270 137-149. (doi:10.1016/j.tox.2010.02.008)

Newbold RR, Padilla Banks E, Jefferson WN \& Heindel JJ 2008 Effects of endocrine disruptors on obesity. International Journal of Andrology 31 201-208. (doi:10.1111/j.1365-2605.2007.00858.x)

Okada H, Tokunaga T, Liu X, Takayanagi S, Matsushima A \& Shimohigashi Y 2008 Direct evidence revealing structural elements essential for the high binding ability of bisphenol A to human estrogen-related receptor- $\gamma$. Environmental Health Perspectives 116 32-38. (doi:10. 1289/ehp.10587)

Okuda K, Takiguchi M \& Yoshihara S 2010 In vivo estrogenic potential of 4-methyl-2, 4-bis (4-hydroxyphenyl) pent-1-ene, an active metabolite of bisphenol A, in uterus of ovariectomized rat. Toxicology Letters 197 7-11. (doi:10.1016/j.toxlet.2010.04.017)

Ranhotra HS 2012 The estrogen-related receptors: orphans orchestrating myriad functions. Journal of Receptors and Signal Transduction 32 47-56. (doi:10.3109/10799893.2011.647350)

Reif DM, Martin MT, Tan SW, Houck KA, Judson RS, Richard AM, Knudsen TB, Dix DJ \& Kavlock RJ 2010 Endocrine profiling and prioritization of environmental chemicals using ToxCast data. Environmental Health Perspectives 118 1714. (doi:10.1289/ehp.1002180)

Richter CA, Taylor JA, Ruhlen RL, Welshons WV \& Vom Saal FS 2007 Estradiol and bisphenol a stimulate androgen receptor and estrogen receptor gene expression in fetal mouse prostate mesenchyme cells. Environmental Health Perspectives 115 902-908. (doi:10.1289/ehp. 9804)

Ritter S 2011 Debating BPA's toxicity. Chemical and Engineering News 89 14-19.

Rochester JR 2013 Bisphenol A and human health: a review of the literature. Reproductive Toxicology 42 132-155. (doi:10.1016/ j.reprotox.2013.08.008)

Ropero A, Alonso Magdalena P, García García E, Ripoll C, Fuentes E \& Nadal A 2008 Bisphenol A disruption of the endocrine pancreas and blood glucose homeostasis. International Journal of Andrology 31 194-200. (doi:10.1111/j.1365-2605.2007.00832.x)

Rubin BS \& Soto AM 2009 Bisphenol A: perinatal exposure and body weight. Molecular and Cellular Endocrinology 304 55-62. (doi:10.1016/ j.mce.2009.02.023) 
Sieli PT, Jasarevic E, Warzak DA, Mao J, Ellersieck MR, Liao C, Kannan K, Collet SH, Toutain P-L, vom Saal FS et al. 2011 Comparison of serum bisphenol A concentrations in mice exposed to bisphenol A through the diet versus oral bolus exposure. Environmental Health Perspectives 119 1260-1265. (doi:10.1289/ehp.1003385)

Soriano S, Alonso-Magdalena P, Garcia-Arevalo $M$, Novials A, Muhammed SJ, Salehi A, Gustafsson JA, Quesada I \& Nadal A 2012 Rapid insulinotropic action of low doses of bisphenol-A on mouse and human islets of Langerhans: role of estrogen receptor $\beta$. PLOS ONE 7 e31109. (doi:10.1371/journal.pone.0031109)

Spivack J, Leib T \& Lobos J 1994 Novel pathway for bacterial metabolism of bisphenol A. Rearrangements and stilbene cleavage in bisphenol A metabolism. Journal of Biological Chemistry 269 7323-7329.

Stahlhut RW, Welshons WV \& Swan SH 2009 Bisphenol A data in NHANES suggest longer than expected half-life, substantial nonfood exposure, or both. Environmental Health Perspectives 117 784-789. (doi:10.1289/ ehp.0800376)

Sugiura-Ogasawara M, Ozaki Y, Sonta S, Makino T \& Suzumori K 2005 Exposure to bisphenol $\mathrm{A}$ is associated with recurrent miscarriage. Human Reproduction 20 2325-2329. (doi:10.1093/humrep/deh888)

Takayanagi S, Tokunaga T, Liu X, Okada H, Matsushima A \& Shimohigashi Y 2006 Endocrine disruptor bisphenol A strongly binds to human estrogenrelated receptor $\gamma($ ERR $\gamma$ ) with high constitutive activity. Toxicology Letters 167 95-105. (doi:10.1016/j.toxlet.2006.08.012)

Tennessen JM, Baker KD, Lam G, Evans J \& Thummel CS 2011 The Drosophila estrogen-related receptor directs a metabolic switch that supports developmental growth. Cell Metabolism 13 139-148. (doi:10. 1016/j.cmet.2011.01.005)

Thayer KA \& Belcher S 2011 Background Paper on Mechanisms of Action of Bisphenol A and Other Biochemical/Molecular Interactions. In: FAO/ WHO Expert Meeting on Bisphenol A (BPA). Ottawa, Canada: WHO Press. http://www.who.int/foodsafety/chem/chemicals/5_biological_activities_of _bpa.pdf

Tremblay AM \& Giguere V 2007 The NR3B subgroup: an ovERRview. Nuclear Receptor Signaling 5 e009. (doi:10.1621/nrs.05009)

Vandenberg LN, Chahoud I, Heindel JJ, Padmanabhan V, Paumgartten FJ \& Schoenfelder G 2010 Urinary, circulating and tissue biomonitoring studies indicate widespread exposure to bisphenol A. Environmental Health Perspectives 118 1055-1070. (doi:10.1289/ehp.0901716)
Vandesompele J, De Preter K, Pattyn F, Poppe B, Van Roy N, De Paepe A \& Speleman F 2002 Accurate normalization of real-time quantitative RT-PCR data by geometric averaging of multiple internal control genes. Genome Biology 3 RESEARCH0034. (doi:10.1186/gb-2002-37-research0034)

Villena JA \& Kralli A 2008 ERR $\alpha$ : a metabolic function for the oldest orphan. Trends in Endocrinology and Metabolism 19 269-276. (doi:10.1016/j. tem.2008.07.005)

Viñas R, Goldblum RM \& Watson CS 2013 Rapid estrogenic signaling activities of the modified (chlorinated, sulfonated, and glucuronidated) endocrine disruptor bisphenol A. Endocrine Disruptors 1 0-9. (doi:10.4161/endo.25411)

Wetherill YB, Akingbemi BT, Kanno J, McLachlan JA, Nadal A, Sonnenschein C, Watson CS, Zoeller RT \& Belcher SM 2007 In vitro molecular mechanisms of bisphenol A action. Reproductive Toxicology 24 178-198. (doi:10.1016/j.reprotox.2007.05.010)

Willy PJ, Murray IR, Qian J, Busch BB, Stevens WC Jr, Martin R, Mohan R, Zhou S, Ordentlich P, Wei P et al. 2004 Regulation of PPAR $\gamma$ coactivator $1 \alpha$ (PGC- $1 \alpha)$ signaling by an estrogen-related receptor $\alpha(E R R \alpha)$ ligand. PNAS 101 8912-8917. (doi:10.1073/pnas.0401420101)

Yan H, Takamoto M \& Sugane K 2008 Exposure to bisphenol A prenatally or in adulthood promotes TH2 cytokine production associated with reduction of CD4 + CD25 + regulatory T cells. Environmental Health Perspectives 116 514-519. (doi:10.1289/ehp.12265)

Ye X, Zhou X, Needham LL \& Calafat AM 2011 In-vitro oxidation of bisphenol A: is bisphenol A catechol a suitable biomarker for human exposure to bisphenol A? Analytical and Bioanalytical Chemistry 399 1071-1079. (doi:10.1007/s00216-010-4344-x)

Yoshihara S, Mizutare T, Makishima M, Suzuki N, Fujimoto N, Igarashi K \& Ohta S 2004 Potent estrogenic metabolites of bisphenol A and bisphenol B formed by rat liver $\mathrm{S} 9$ fraction: their structures and estrogenic potency. Toxicological Sciences 78 50-59. (doi:10.1093/toxsci/kfh047)

Received 4 September 2013

First decision 1 October 2013

Revised manuscript received 21 October 2013

Accepted 14 November 2013 